\title{
A Review of Hazardous Compounds Present in Construction Waste Materials
}

\author{
Elamaran Manoharan*, Norazli Othman, Roslina Mohammad, Shreeshivadasan Chelliapan, \\ Siti Uzairiah Mohd Tobi
}

Razak Faculty of Technology and Informatics, Universiti Teknologi Malaysia, Jalan Sultan Yahya Petra, 54100 Kuala Lumpur,
Malaysia

Received July 6, 2021; Revised August 27, 2021; Accepted September 21, 2021

\begin{abstract}
Cite This Paper in the following Citation Styles
(a): [1] Elamaran Manoharan, Norazli Othman, Roslina Mohammad, Shreeshivadasan Chelliapan, Siti Uzairiah Mohd Tobi, "A Review of Hazardous Compounds Present in Construction Waste Materials," Environment and Ecology Research, Vol. 9, No. 5, pp. 224 - 234, 2021. DOI: 10.13189/eer.2021.090503.
\end{abstract}

(b): Elamaran Manoharan, Norazli Othman, Roslina Mohammad, Shreeshivadasan Chelliapan, Siti Uzairiah Mohd Tobi (2021). A Review of Hazardous Compounds Present in Construction Waste Materials. Environment and Ecology Research, 9(5), 224 - 234. DOI: 10.13189/eer.2021.090503.

Copyright $\odot 2021$ by authors, all rights reserved. Authors agree that this article remains permanently open access under the terms of the Creative Commons Attribution License 4.0 International License

\begin{abstract}
Construction industry around the world is well-known as a massive contributor of waste materials and environmental impacts. Among the types of waste materials generated by this industry are concrete, plastic, wood, ceramic, and asbestos. These waste materials, in general, are chemically fused through various manufacturing processes before being transported for the construction usage. Addition of chemical compounds such as arsenic, copper, cyanide, nickel, chromium, lead, sulphate, and zinc are mainly for enhancing the mechanical and physical properties of the materials so that the materials could last longer, perform well and withstand external forces. However, construction materials that are made up of these chemical compounds are threatening the nature and human beings once the materials are used up and the leftover from the construction industry are thrown away without proper waste management practice. The aim of the study was to review hazardous compounds presented in construction waste materials and suggest ways to manage it effectively. The methodology is literature review, data collection from published articles, and data analysis. Findings from this study showed that concrete, plastic, wood, ceramic, and asbestos are among the waste materials that are made up of hazardous compounds, which impact the environment and mankind living today. As a mitigation measure, a proper waste management practice is necessary among the construction practitioners to protect humans and
\end{abstract}

biological factors, save some landfill spaces, preserve some natural resources, prevent soil and underground water channel contamination, avoiding illegal dumping activities, and promotes sustainability factors. Obeying the enforced rules and regulations, utilisation of various waste management technologies, on-site waste segregation and proper storage, waste substitutions, and making use of well-structured framework developed by researchers and construction consultancy are among the methods that can be adopted in polishing the current waste management practice.

Keywords Concrete, Ceramic, Wood, Plastic, Asbestos

\section{Introduction}

Over the past few decades, Malaysian economy was facing rapid development and ranked 18th globally competitive country in 2015 [1]. As one of the key players to the development of Malaysian economy, the construction industry was granted with numerous projects worth up to RM 138 billion in 2017 to achieve the demands of the population [2]. However, the extreme urbanisation that was involved by this industry significantly changed the lifestyle of the population and 
contributed to habitat destruction, heat island, excessive waste generation, and emission of carbon dioxide to the environment [1]. Focusing on the number of waste generation, Malaysian construction industry recorded almost 300 tonnes of daily waste materials in 2015 and estimated up to 370 tonnes in 2023 [3]. Ministry of Housing and Local Government MHLG 2012 in [4] stated that the projected waste amounts are believed to occupy around $40 \%$ of the total solid waste stream in Malaysia on a daily basis and are made up of complex materials such as concrete, glass, plastic, ceramic, and wood. Construction waste materials are much more complex compared to other waste materials generated by industries such as household, manufacturing, automobile and agriculture due to the nature of construction material manufactured with various compounds which include hazardous elements such as asbestos and volatile organic compounds to enhance the physical and chemical properties [13].

In general, hazardous waste materials generated from various industries around the world possess harmful properties to the human beings and environment. Hazardous waste materials are in several states such as solid, liquid, and gas which mainly diffuse to the environment that we are living in today. Studies reported that hazardous waste materials could be any product that is made up of chemicals. Significant numbers of heavy metals are relatively toxic to the environment if proper waste management practice is not implemented [5].

The Star, in a statement, highlighted that out of the total numbers of construction waste materials generated on-site, only $15 \%$ are picked up by the appointed solid waste collectors while the rest end up in nearby landfills that include illegal dumping activities whereby no proper waste management practice is conducted [6]. The director of the Department of Environment (DOE) in Malaysia stated that the waste materials that end up in landfills could be toxic and should be treated before being landfilled in order to avoid any unwanted impact on water, air, and soil in the near future [6]. Thus, this article was believed to provide some useful information to the readers on the presence of hazardous compounds in the construction waste materials and the way to manage it effectively based on the information that gathered from previously published articles. Among the waste materials highlighted in this study were concrete, plastic, ceramic, wood, and asbestos. These waste materials were chosen based on its proven entries of hazardous compounds and common generation on-site.

\section{Hazardous Construction Waste Materials}

\subsection{Concrete}

Almost $66 \%$ of the total construction waste generated in
Malaysia is made up of concrete and aggregate [6]. This is due to the nature of design and build in Malaysian projects that are made up of concrete structures. Basically, a concrete waste material was made up of cement, coarse aggregate, fine aggregate, admixtures and right amount of water to achieve the desired bonding for civil structures $[7,8]$. It is recorded that almost 25 billion tonnes of concrete materials are produced on an annual basis throughout the world to fully fill the demand from construction parties [7]. These huge amounts of concrete supply accounted as the largest portion compared to other construction materials ordered by the construction industry. Thus, the higher the demand and supply of concrete materials, the higher the number of waste materials generated [21]. This is the major reason for concrete related industries around the world to be known as the massive contributor to the waste materials and the environment impacts [22].

The concrete materials are wasted at the construction site due to the order of inappropriate amounts and the design mix error by the batching plants which fail to be in the range of approved slump once the concrete is poured and tested from the ready mixed truck $[8,9]$. Concrete materials that are wasted or rejected from the ready mixed truck at the construction site are made up of cement in the highest proportion that possesses several hazardous compounds to increase the strength, durability and maintain the right setting time in cold and hot weather. In the European scenario, there are 27 types of cement used for the construction industry that are manufactured through various chemical reactions in the cement production units [17]. However, the most common type of cement being ordered is Portland cement, not only in the European region but also in the Malaysian scenario which is made up of two types: Ordinary and Pozzolana Portland Cement. Among the hazardous compounds related to the cement during manufacturing processes are mercury, cadmium, and particularly gypsum as clinker which is listed in the scheduled waste by the Department of Environment (DOE) Malaysia [10,11]. Briefly, scheduled waste is a waste material that is categorised as harmful waste and needs proper waste management practice before the final disposal activity. To date, 77 types of scheduled wastes have been listed by the Department of Environment (DOE) to be impactful to the human beings and environment if simply disposed of in landfill. When related to the concrete waste material, the gypsum present in cement material is coded as SW205 in the list of scheduled wastes and not environmentally friendly material [12].

Apart from mercury, cadmium, and gypsum, the concrete waste materials generated from the construction industry are made up of arsenic, cyanide, nickel, chromium, lead, sulphate, and zinc which possess leaching characteristics if simply landfilled. Most of these heavy metals were figured out by Sealey et al. [14] when 
conducting a study on $\mathrm{pH}$ value of fresh concrete waste at the ready mixed plants that batched for site delivery. Major concern should be given to the compounds such as chromium, cadmium, nickel, and mercury that cause skin irritation and allergic reactions when leachates from disposed concrete waste materials or solvents come in contact with the cement and concrete workers in the manufacturing and construction industry [15]. Both skin irritation and allergies are believed to be due to alkalinity and concentration of heavy metals used in the concrete materials [16]. Usually, irritation or burning sensation starts to occur when $10 \mathrm{mg}$ of chromium is added to $1 \mathrm{~kg}$ of cement material in the production unit [23].

On the other hand, a study conducted by Achternbosch et al. [17] stated that a concrete material is manufactured by considering the capability to withstand the environmental changes during its life period and once the material gets disposed of under the soil. Within the capability, the concrete material will not produce any leachate under any circumstances or conditions. However, when changes in environment get extreme and alternate in short period of time particularly in the region with sudden hot and cold weather, the concrete material could not adapt to the situation and might produce leachate to the soil, where the material was disposed of. Besides that, the level of corrosion through acidic value present in nature could induce the formation of leachate and this situation worsened if the concrete waste materials were crushed instead of disposing in the solid form. Produced leachate with heavy metals tended to move within the soil affecting the biological factors and mixed with water sources particularly chromium which reported with higher leaching characteristic compared to other compounds presented in the concrete material under any $\mathrm{pH}$ value [20].

Chromium compound presented in the cementitious material is made up of several types. The most common type used in the cement manufacturing unit is chromium type-four. Chromium type-four is the most hazardous and dangerous compound compared to other types of chromium due to the level of chemical exposure, better movement in any platform, and higher level of solubility in a chemical solvent or third-party agent such as water source [23]. Usage of this particular type of compound in the cement should be prohibited since cement products are used for various purposes including water tanks and common pipeline system construction for households and industries around the world. Concrete materials that are made up of cement in the highest proportion with presence of chromium type-four are capable to dissolve in the water supply used as drinking water and thereby, affect the human health $[23,24,25]$. Apart from chromium as a hazardous compound, affected water sources with leachate from concrete waste materials are believed to affect human health with another impactful compound called Barium that can be found on the surface of water sources [18]. Barium is another compound used in the cement manufacturing industry to produce a clinker and used as an agent against any radiation to the solid hardened concrete in the construction industry. Barium is proven to be more effective than lead in protecting the concrete surface of a building since its notable capability to maintain the surface in strong hardened state for a long period of time [19]. Thus, the usage of Barium compound seemed popular in the cement manufacturing industry and directly contributed to the environmental impacts once the concrete material made up of it was wasted and simply dumped from the construction industry.

\subsection{Plastic}

Plastic materials are generally not seen as much as usage of concrete, wood and glass in the construction industry. However, these materials are widely used in various tools, parts and fittings such as windows, doors, pipes, building finishes and packaging of building materials which include plastic bottles and containers to ease the transportation activities. Usage of plastics are gaining popularity in the construction industry due to the cost of material, better insulation properties, consume not much of time for installation and last longer with less maintenance. In the European region, the construction industry stands next to the packaging industry in the number of plastic materials consumed. It is reported that approximately 10 million tonnes of plastic materials are consumed by the construction industry annually for various purposes in the daily site operations [26]. Out of these numbers, around 50000 tonnes of plastics are being wasted in the United Kingdom [27] and most of it is made up of polyvinyl chloride (PVC) [26].

Awoyera and Adesina [28] stated that plastic waste materials have greatly increased on an annual basis throughout the world but only a certain amount are managed and landfilled in the right method while the rest disposed of illegally and find its way to the marine ecosystem which directly affecting the biological factors and depleting the uniqueness of water bodies such as oceans and seas. Plastic waste materials are made of a series of polymers that are chemically combined by using several hydrocarbons. Among the hydrocarbons used for plastic manufacturing are propylene and ethylene. These hydrocarbons are fusion of carbon and hydrogen compounds which are basically obtained through extraction of crude oil in the refinery [29]. There are two major categories of plastics formed through the combination of propylene and ethylene in a long chain of polymers. Among the types are thermoplastics and thermosets. Thermoplastics are studied for their ability to reform into different shapes and conditions while thermosets do not permit any alteration once formed and cooled [30]. The most common category for construction plastic material is thermoplastics and as mentioned earlier 
PVC is one of the resins in this category that is highly wasted in the construction industry in the form of pipes, containers, and other fittings [26].

Plastic materials may have various advantages in industries and societies. However, the compounds used for plastic productions are highly dangerous in terms of level of toxicity and affect the human health and environment if the compound leak out from the construction plastic materials that are wasted and dumped over a long period of time [31]. Commonly, plastic materials consist of threatening compounds to the mankind such as bisphenol A, phthalates, brominated elements, poly-fluorinated trace chemicals and antimicrobial additives [32]. Out of these compounds, bisphenol A and phthalates are known as a major contributor to varieties of plastic products manufactured around the world. When related to the PVC materials in the construction industry, bisphenol A is used as chemical additive while phthalates are responsible for increasing the strength and flexibility to a longer period of time [32]. However, phthalate is a chemical compound which possesses structural changes behaviour and might leak out from the plastic materials since the phthalate bond in the series of plastic polymers is not chemically fused or in permanent state [33].

Apart from bisphenol A and phthalate in the series plastic polymers, PVC materials including pipes used for construction works are learned to be manufactured with additional hazardous compounds such as crater, cadmium, dioxins and led [31]. When these materials are not disposed of in the right method after the period of life cycle, the hazardous compounds might get leached to the environment. This is one of the reasons for the detection of bisphenol A and phthalate by researchers on the surface of water bodies [34,35] since these compounds are not chemically fused [33] and might have dissolved after several movements of water molecules against the waste materials. Dissolved hazardous compounds in the water bodies threaten human health when people consume it as normal drinking water to sustain life. These compounds were researched and have proven to affect human health in terms of internal organ failure such as liver, cancer through carcinogen properties, digestion issues particularly to the aging peoples, skin problems, and some changes in genetics [31,32]. Regardless of compounds in the plastic waste materials, exposure of sunlight energy continuously on the disposed plastic material tends to destroy the structures and within a certain period of time, the plastic material breaks down and forms into smaller size identified as micro plastic chips [36, 37]. These micro-chips will remain in the environment and start to be mixed with nearest water bodies since plastic materials are non-biodegradable and could not be decomposed by nature even though the materials are broken into smaller sizes [38]. Mixed microchips in the water bodies tend to be consumed by aquatic animals and end up in the human body through the food supply chain system [39] which affects human health overall. Thus, serious concern should be given to the overwhelming of plastic waste materials particularly from the construction industry in order to minimise the impacts on environment and human health.

\subsection{Ceramic}

Ceramic products such as ceramic floor, wall and roof tile, brick, and sanitary ware contribute to some portions of the waste materials that accumulate at construction sites [42]. As an active supplier of ceramic materials to the construction industry, the ceramic manufacturing industry in Malaysia recorded an approximately 92 million $\mathrm{m}^{2}$ of the ceramic tiles production in the year of 2018 [40]. During the production stage, almost $30 \%$ of the ceramic wastes are generated and most of it landfilled due to the use of ceramic wastes are not widely explored [40, 47]. Ceramic tiles that are manufactured and supplied to the construction industry are used as finishes to the constructed walls and floors in a particular project. Based on a study conducted by Balegh et al. [41] on the chemical composition of ceramic waste, $66 \%$ of the waste sample is made up of Silicon Dioxide $\left(\mathrm{SiO}_{2}\right), 14 \%$ Aluminium Oxide $\left(\mathrm{Al}_{2} \mathrm{O}_{3}\right), 6.7 \%$ Calcium Oxide $(\mathrm{CaO})$ and $3.6 \%$ with Iron Oxide $\left(\mathrm{Fe}_{2} \mathrm{O}_{3}\right)$. In South Africa, ceramic waste from construction and demolition activities is classified as problematic waste [Initiative for Zero Waste in Africa (IZWA) in 43] and only suits for landfilling due to lack of research and findings on a better way to manage it. However, it is stressed that the only landfilling method not a best option due to landfilling of the ceramic waste from the construction industry could induce the formation of leachate with chemical compounds since open landfilling processes are exposed to unstable environmental conditions [44]. Furthermore, Singh and Srivastava [45] supported that formation of leachate with chemical compounds from the landfilled construction ceramic wastes might degrade the soil and be mixed with groundwater supply. Affected soil area with liquid formed leachate does not permit any sorts of agricultural activity since the soil loses its fertility to encourage the development of crops. Moreover, ceramic products are manufactured with stains and glazes. Addition of these sub-materials to the ceramic production batch proven to be made of toxic compounds such as cadmium, copper, cobalt, lead, manganese, antimony, vanadium, selenium, and barium [46] that possess high leaching characteristics to the medium it gets disposed of once the products are used up and thrown away from the construction industry.

Commonly, ceramic waste generation and accumulation is not obvious at construction sites. Most of the published articles were focused on the ceramic waste generation from the manufacturing industry since the volume of ceramic wastes from cutting and polishing are obvious 
and much considerable. Even in the Malaysian construction industry, there are minimal amounts of on-site ceramic waste generations which are disposed of as mixed waste. However, a study reported that $45 \%$ of detected ceramic wastes in the environment are from construction and demolition activities [48]. Higher number of detectable ceramic wastes in the environment offers hazards to the human beings and quality of the surrounding environment. For instance, ceramic waste disposal in terms of powder can induce dust pollution and degrade the quality of air [49]. Ceramic dust particles that mostly made up of silica in the surrounding air have been stated to affect the human breathing system by the United State Department of Labor [50]. It is added that inhalation of silica from the ceramic waste powder could lead to lung cancer and even fatal when a person has a prolonged exposure since silica is a chemical compound that is used in a higher composition during the manufacturing processes of ceramic products [50].

In contra, studies claimed that ceramic wastes in general are classified as non-hazardous since the materials used for the production are obtained naturally [42,52]. It was also stated that tile as one of the ceramic products that is widely used in the construction industry does not pollute the surrounding environment once the material is wasted and disposed of from the particular project. The waste material is stated to be free from any harmful compound [52]. However, [46] stated that working with ceramics is highly dangerous to the human health especially when the ceramic produces waste powder [50]. In construction industry, ceramic wastes can be found in solid and powered form which resulted from tile cutting and alteration on constructed brick wall. The solid waste materials are commonly disposed of by licensed waste collectors while the powdered form is taken off by open air movement, which is contaminated and caused harmful effects if breathed in by human beings.

\subsection{Wood}

Wood waste from the construction industry is quantitatively notable from the total volume of waste generation [55]. Wood often categorised as an environmentally friendly or natural material. However, a certain construction wood material would undergo a set of chemical treatment such as addition of copper compound and application of varnish, paint or solvent to protect the surface layer from third party agents [53]. In paint, there are two grading, water-dependent paint and oil-dependent paint [61]. Both listings are presented with hazardous elements and need a proper waste disposal practice. Among the hazardous elements are cadmium, selenium, arsenic, lead and mercury [61]. Some non-visible wood treatments can be identified from collection of samples and further tests. The purpose of virgin wood treatment is to prolong its life cycle by getting away of any unwanted wood structure impairment commonly caused by water molecules, bacteria, fungi and termites [54]. Treated construction wood waste materials that reached its end of life could be harmful to the mankind and surrounding environment if improperly disposed of. This is due to treated wood wastes are often contained some threatening compounds that needed a proper waste management practice. Thus, concern on related construction wood materials is getting increased due to the environmental impacts associated once the materials wasted and disposed of from the construction site [56].

Usage of chemical to treat a virgin wood for construction purpose has been in practice since hundreds of years [57]. Among the chemicals used are chromium, copper, and arsenic [58]. Chromium, copper, and arsenic, not only in wood wastes, but also in some other construction wastes such as concrete and ceramic are toxic or hazardous compounds that threaten human and surrounding environment. Addition of chromium, copper and arsenic compound in wood materials are widely implemented in the building sector due to the extended life cycle up to 25 years and its suitability to be used for outdoor construction activities such as landscape, playground, fence and outdoor home decoration for a pleasant and luxury view [57,59]. Some portions of treated wood materials with these hazardous compounds are wasted during the construction processes and disposed of in the landfill. In the US, Australia, and Canada, treated wood wastes from the building sector are disposed of in the landfill without any prior treatment on hazardous compounds removal [57]. However, concern on environmental contamination from chromium, copper, and arsenic from the waste wood arise due to these compounds possessing leaching characteristic once they are simply disposed of in the landfill [60].

\subsection{Asbestos}

Asian countries are popular in asbestos usage for various purposes due to their notable properties such as good heat and fire insulation, longer life, flexibility, cheapness, and relative stability over time $[62,63,64]$. However, some countries in the European region put some restrictions on the usage of asbestos materials due to adverse environmental and health impacts associated. In building industry, when a project is under construction or deconstruction, asbestos-related dust or asbestos dust waste in the surrounding air should be a concern for the appointed contractor. This is because inhalation of asbestos dust wastes has been studied to have cancer-inducing property (also known as carcinogenic) [62,65]. World Health Organization (WHO) [65] reported that over one hundred thousand people worldwide have died due to asbestos related complication. Asbestos exposure could be from construction or manufacturing industry, where the workers are highly engaged with the 
asbestos related products. When related to the construction industry, asbestos materials are commonly used in plumbing works such as pipe and fitting, roofing works, floors [66] and outdoor works as stated earlier. All these particular works are carried out by considering the insulation properties of the materials, by which asbestos suits well. Asbestos materials are manufactured with a property known as fibres. During installation in the necessary parts of building, limited pressure or stress should be given to the asbestos materials. Otherwise, asbestos materials might crack and the fibres could mix with the open air. Mixed asbestos fibres or asbestos dust waste in the air possess higher chances to be inhaled by construction workers, whereby the fibres could be trapped in the human lungs and cause severe health issues [66]. The fibres are not digested easily or absorbed by the human fluid system due to its properties that can withstand any physical condition [67]. Therefore, during the installation of asbestos-related materials in the construction industry, care should be taken by experienced workers or special asbestos workers and proper personal protection equipment should be worn prior to the activities such as general roofing or plumbing labours. When an asbestos fibre is trapped or passed through the human lungs, it can affect other human organs through translocation [68].

\section{Management of Construction Waste Materials}

Construction industry around the world has taken some initiatives on implementation of sustainable development program by utilising the environmentally friendly technologies in various building processes [69]. With advancement of sustainable technologies in the era of IR 4.0, Hong et.al [70] have raised an issue on the hazardous pollutants that occurring at the construction site and possible ways to manage it in a sustainable manner. Hazardous pollutants or contaminations at the construction site could be from the construction processes itself or through the on-site waste material generation. The authors [70] suggested the three main technologies (monitoring, evaluation, and improvement) in the management of on-site hazardous pollutants. Monitoring technology involves capturing the level of hazardous contamination around the construction site which resulted from construction activities. In evaluation, the data is monitored, evaluated, and action is taken if the level of contaminations is threatening to the human and surrounding environment while in the improvement technology, impact of hazardous construction pollutants or contaminations on the surrounding environment and peoples is assessed and minimised to achieve the sustainable factors in the construction industry [70]. In every second, approximately 13 tonnes of hazardous waste are generated worldwide. Hazardous waste from the construction industry is in any form. It could be solid, liquid, gas, or vapour [71]. These hazardous waste materials that result from the construction and demolition activities should be stored in a proper airtight container and covered with a waterproof agent so that no any leakage occurs. Waterproof agent is useful in preventing the waste materials from getting mixed with soil and running water. Every container needs to be labelled and marked in worksheet before taken off by the waste management collectors for further processes [71]. On-site waste management is an important aspect that should be concerned by the contractors prior to other waste management facilities since waste segregation, storage and right labelling assist and motivate the respective parties in further waste management processes rather than mixing waste that is caused by the traditional disposal methods such as landfilling.

Moreover, waste substitution to a raw material is also a popular method of hazardous waste materials management. For example, the capability of crushed concrete waste to partially substitute the usage of natural aggregate in various construction activities such as substitution to a layer in road or highway construction, as a sub layer prior to reinforcement set up in a concreting task and as filler to holes and gaps in brick wall, drainage, and septic tank [72]. On the other hand, concrete waste as a substitute to the natural aggregate in the form of recycled concrete aggregate is considered as an important aspect in the construction waste management. Disposal of hardened concrete waste always consume a larger space in landfill. Therefore, usage of recycled concrete aggregate is believed to save some landfill spaces, preserve some natural resources, prevent soil and underground water channel contamination, protect human and biological factors, avoid illegal dumping activities, and at the same time promotes sustainability factors [73].

Countries around the world have certain rules and regulations on generation and management of construction waste materials. Wahi et. al [74] compared imposed rules and regulations in Hong Kong and Malaysia and explained the established ordinances in Hong Kong which relate to the construction waste management such as proper waste disposal methods, banned on illegal dumping activities, concerns on air quality during the construction processes, well use of designed flowchart on waste control, and management and necessity on impacts reduction through a well-structured environmental assessment [75,76,77]. In Malaysia, there are two main Acts which are enforced to reduce, reuse and recycle the construction waste materials to prevent the environmental impacts. These practices are compulsory for construction practitioners. Severe penalties would be imposed if the practitioners do not obey the rules and legislations. Among the Acts are Act 672 and Act 127 [78,79,51].

In addition to a proper waste management practice, 
LEED principle in the construction industry is widely implemented around world. The principle originated from the United States (US) and it is used as an indicator to obtain a certified healthy green building. LEED, also known as Leadership in Energy and Environmental Development, has an important indicator related to the construction waste management practice whereby a construction practitioner should achieve $75 \%$ of on-site waste reusage or recycling to be eligible for LEED certification to the particular project. At the moment, statistics showed that approximately 34000 projects in the US and 1500 in China managed to get LEED certification. Adoption of LEED principle would be an advantage to Malaysian construction industry in minimising the common and hazardous waste disposal at landfills $[82,83]$. Besides that, Life Cycle Assessment (LCA) is a well-known tool used globally in the construction waste management system. LCA tool plays a major role in identifying the potential environmental impacts from utilisation of varies waste management technologies such as reuse, recycling, recovery and waste disposal [80]. It is also clarified that Implementation of LCA in the construction waste management system has shown a clear path on effective waste management practice from the view point of waste generation at the construction site until the point of disposal in the landfill by maximising the possible ways to convert the waste materials into a meaning factor and used back in the respective industries rather than simply landfilled and thereby, depleting the natural resources [81 in 80]. Throughout the LCA processes, certain level of emissions towards the environment is expected in the form of air, water, and residual. However, pre-treatment of expected level of emission before releasing to the environment could avoid the environmental contamination.

\section{Conclusions}

In conclusion, construction waste material generation of hazardous compounds at building sites is threatening the nature and human health if proper waste management practices are not implemented by the construction practitioners. Among the common hazardous compounds are arsenic, cyanide, nickel, chromium, lead, sulphate, and zinc which possess leaching characteristics if simply landfilled. Several waste management methods can be adopted by the construction parties to effectively manage the massive amount of building related waste materials. Obeying the enforced rules and regulations, utilisation of various waste management technologies, on-site waste segregation and proper storage, waste substitutions, and make use of well-structured framework developed by researchers and construction consultancy in managing the wastes from generation till disposal. The study mainly addressed the situation in Malaysia. However, data and practices from the UK, US, Hong Kong, and Canada were presented and discussed throughout the study as a guide for a better waste management practice that can be adopted by the Malaysian construction practitioners if the scenarios and way of implementations are suitable in our region. The study was limited to the five types of waste materials that are generated on-site. Further research needs to be done for better outcome and understanding in the field.

\section{Acknowledgements}

The authors would like to express their greatest appreciation and utmost gratitude to the Ministry of Higher Education and Universiti Teknologi Malaysia (UTM) for all their support in making this study a success. Vote: $16 \mathrm{~J} 53$

\section{REFERENCES}

[1] World Economic Forum., "The Global Competitive Index 2015-2016 Report, Geneva, Switzerland,” pp. 248, 2015. http://www3.weforum.org/docs/gcr/2015-2016/Global_Co mpetitiveness_Report_2015-2016.pdf

[2] Rahim M. H. I. A., Kasim N., Mohamed I., Zainal R., Sarpin N., Saikah M., "Construction Waste Generation in Malaysia Construction Industry: Illegal Dumping Activities," IOP Conference Series: Materials Science and Engineering, vol. $271 \quad$ (012040), 2017. DOI:10.1088/1757-899X/271/1/012040

[3] Fauziah S. H., Agamuthu P., "Municipal Solid Waste Management: A Comparative Study in Selected Landfills in Selangor in Proceedings of Environment," Environmental Management and Sustainable Development for Better Future Growth, Penang, Malaysia, pp. 434- 437, 2003. https://scholar.google.com/scholar?hl=en\&as_sdt=0 $\% 2 \mathrm{C} 5 \& \mathrm{q}=\% 5 \mathrm{~B} 3 \% 5 \mathrm{D}+$ Fauziah $+\mathrm{S} .+\mathrm{H} . \% 2 \mathrm{C}+$ Agamuthu $+\mathrm{P}$. $\% 2 \mathrm{C}+\% \mathrm{E} 2 \% 80 \% 9 \mathrm{CMunicipal}+$ Solid+Waste+Managemen $\mathrm{t} \% 3 \mathrm{~A}+\mathrm{A}+\mathrm{Comparative}+$ Study+in+Selected+Landfills+in+ Selangor+in+Proceedings+of+Environment $\% 2 \mathrm{C} \% \mathrm{E} 2 \% 80$ $\% 9 \mathrm{D}+$ Environmental+Management+and+Sustainable+Dev elopment+for+Better+Future+Growth $\% 2 \mathrm{C}+$ Penang $\% 2 \mathrm{C}+$ Malaysia\%2C+pp.+434-+437\%2C+2003.\&btnG=

[4] Mei M. A. H. C., Fujiwara T., "A survey of Construction and Demolition Waste in Malaysia, Mixed-Use Development," Journal of the Faculty of Environmental Science and Technology, Okayama University, vol. 21, no. 1, pp. 1-2, 2016. http://www.est.okayama-u.ac.jp/up_load_ files/freetext/pre_up/03-1_Mei.pdf

[5] National Institute of Environmental Health Sciences (NIEHS)., "Hazardous Materials / Waste, In Health and Education," 2019.https://www.niehs.nih.gov/health/topics/ agents/haz-waste/index.cfm

[6] The Star., "Aiming for Zero Construction Waste by 2030," 2015. https://www.thestar.com.my/metro/community/2015 /11/20/aiming-for-zero-construction-waste-by-2030-semin 
ar-looks-at-adopting-sustainable-practices-in-a-bid/

[7] The Borneo Post Online., "Concrete Waste: Discard or recycle," 2012. https://www.theborneopost.com/2012/10/3 $1 /$ concrete-waste-discard-or-recycle/

[8] Abu Eusuf M., Ibrahim M., Islam R., "The Construction and Demolition Wastes in Klang Valley, Malaysia," Journal of the Malaysian Institute of Planners, X, pp. 99-124, 2012. DOI: 10.21837/pmjournal.v10.i3.103

[9] Poon C. S., "Low-waste Building Technologies and Practices. In Concrete Work," The Hong Kong Polytechnic University, Hong Kong, 2004. http://www.zn903.com/cecs poon/lwbt/index.html

[10] Stephen Z., Michael A., Laura G., Maria J. B., David G., Igor L., José P. O., "Emissions of Metals and Polychlorinated dibenzo (p) dioxins and Furans (PCDD/Fs) from Portland Cement Manufacturing Plants: Inter-kiln Variability and Dependence on Fuel-types," Science of the Total Environment, vol. 409, pp. 4198-4205, 2011. https://doi.org/10.1016/j.scitotenv.2011.06.047

[11] Jamin N. C., Mahmood N. Z., "Hazardous Waste Management in Malaysia: A Case Study on Cement Manufacturing," International Conference on Environmental Forensics (iENFORCE2015), Procedia Environmental Sciences, pp. 000-000, 2015. DOI: 10.13140/RG.2.1.3646.2808

[12] Department of Environmental (DOE)., "Scheduled Wastes Information, Ministry of Environment and Water, Putrajaya, Malaysia," 2020. https://www.doe.gov.my/porta lv1/en/

[13] Esin T., Cosgun N., "A Study Conducted to Reduce Construction Waste Generation in Turkey," Building and Environment, vol. 42, pp. 1667-1674, 2007. https://doi.org/10.1016/j.buildenv.2006.02.008

[14] Sealey B. J., Phillips P. S., Hill G. J., "Waste Management Issues for the UK Ready-mixed Concrete Industry," Resources, Conservation and Recycling, vol. 32, pp. 321-331, 2001. https://doi.org/10.1016/S0921-3449(01)00 069-6

[15] Estokova A., Oravec J., Ondova M., "Study of Heavy Metals Releasing from Concrete Composites," 14th International Multidisciplinary Scientific GeoConference SGEM, Ecology and Environmental Protection, 2014. https://www.researchgate.net/publication/293110210_Stud y_of_heavy_metals_releasing_from_concrete_composites

[16] Chen C. J., Shih T. S., Chang H. Y., Yu H. S., Wu J. D., Sheu, S. C., Wu C. E., Chou T. C., "The Total Body Burden of Chromium Associated with Skin Disease and Smoking among Cement Workers," Science of the Total Environment, vol. 391, no. 1, pp. 76-81, 2008. https://doi.org/10.1016/j.scitotenv.2007.11.011

[17] Achternbosch M., Brautigam K. R., Hartlieb N., Kupsch C., Richers U., Stemmermann P., "Heavy Metals in Cement and Concrete Resulting from the Co-incineration of Wastes in Cement Kilns with Regard to the Legitimacy of Waste Utilisation," Wissenschaftliche Berichte des Forschungszentrums Karlsruhe, FZKA 6923, Refer in Article, pp. 006 and 106, 2003. http://www.itas.kit.edu/pub /v/2003/acua03b.pdf
[18] Ohgami N., Hori S., Ohgami K., Tamura H., Tsuzuki T., Ohnuma S., Kato M., "Exposure to Low-dose Barium by Drinking Water Causes Hearing Loss in Mice," NeuroToxicology, vol. 33, no. 5, pp. 1276-1283, 2012. DOI: $10.1016 /$ j.neuro.2012.07.008

[19] Zezulova A., Stanek T., Opravil T., "The Influence of Barium Sulphate and Barium Carbonate on the Portland Cement. International Conference on Ecology and New Building Materials and Products, ICEBMP," Procedia Engineering, vol. 151, pp. 42-49, 2016. DOI: 10.1016/j.proeng.2016.07.358

[20] Yang Y., Yang Y., Wang Q., Huang Q., "Release of Heavy Metals from Concrete Made with Cement from Cement Kiln Co-Processing of Hazardous Wastes in Pavement Scenarios," Environmental Engineering Science, vol. 28, no. 1, pp. 35-42, 2011. https://doi.org/10.1089/ees.2010.00 66

[21] Gordon L. E., San Nicolas R., Provis J. L., "Chemical Characterisation of Metakaolin and Fly Ash based Geopolymers during Exposure to Solvents used in Carbon Capture," International Journal of Greenhouse Gas Control, vol. 27, 2014. https://doi.org/10.1016/j.ijggc.2014.06.005

[22] He X., Zheng Z., Ma M., Su Y., Yang J., Tan H., Wang Y., Strnadel B., "New Treatment Technology: The Use of Wet-milling Concrete Slurry Waste to Substitute Cement," Journal of Cleaner Production, vol. 242, 2020. https://doi.org/10.1016/j.jclepro.2019.118347

[23] Estokova A., Palascakova L., Kanuchova M., "Study on Cr (VI) Leaching from Cement and Cement Composites," International Journal of Environmental Research and Public Health, vol. 15, no. 4, 2018. https://doi.org/10.3390/ijerph15040824

[24] Sazakli E., Villanueva C. M., Kogevinas M., Maltezis K., Mouzaki A., Leotsinidis M., "Chromium in drinking water: Association with biomarkers of exposure and effect," International Journal of Environmental Research and Public Health, vol. 11, no. 10, pp. 10125-10145, 2014. DOI: $10.3390 /$ ijerph111010125

[25] Shi P., Xiao J., Wang Y., Chen L., "Assessment of Ecological and Human Health Risks of Heavy Metal Contamination in Agriculture Soils Disturbed by Pipeline Construction," International Journal of Environmental Research and Public Health, vol. 11, no. 3, pp. 2504-2520, 2014. DOI: $10.3390 /$ ijerph110302504

[26] Plastics Europe., "Association of Plastics Manufacturers, Plastics in Building and Construction. In Portal: About Plastics," 2020. https://www.plasticseurope.org/en/about-p lastics/building-construction

[27] Building., "Plastic Waste in Construction - Is the Sector Doing Enough? In Portal: Focus," 2019. https://www.building.co.uk/focus/plastic-waste-in-construc tion-is-the-sector-doing-enough/5098139.article

[28] Awoyera P. O., Adesina A., "Plastic Wastes to Construction Products: Status, Limitations and Future Perspective. Case Studies in Construction Materials," vol. 12, 2020. https://doi.org/10.1016/j.cscm.2020.e00330

[29] Chen S., Liu Z., Jiang S., Hou H., "Carbonization: A Feasible Route for Reutilization of Plastic Wastes," Science of the Total Environment, vol. 710, 2020. 
https://doi.org/10.1016/j.scitotenv.2019.136250

[30] Plastics Europe., "Association of Plastics Manufacturers. How Plastics are Made? In Portal: About Plastics," 2020. https://www.plasticseurope.org/en/about-plastics/what-areplastics/how-plastics-are-made

[31] Proshad R., Kormoker T., Saiful Islam Md., Haque M. A., Mahfuzur Rahman Md., Rahman Mithu Md M., "Toxic Effects of Plastic on Human Health and Environment: A Consequences of Health Risk Assessment in Bangladesh," International Journal of Health, vol. 6, no. 1, pp. 1-5, 2018. DOI: 10.14419/ijh.v6i1.8655

[32] Halden R. U., "Plastics and Health Risks," Annual Review of Public Health, vol. 31, pp. 179-194, 2010 https://www.annualreviews.org/doi/10.1146/annurev.publh ealth.012809.103714

[33] [33] Wagner M., Oehlmann J., "Endocrine Disruptors in Bottled Mineral Water: Total Estrogenic Burden and Migration from Plastic Bottles," Environmental Science and Pollution Research, vol. 16, pp. 278-286, 2009. DOI: $10.1007 / \mathrm{s} 11356-009-0107-7$

[34] Rudel R. A., Brody J. G., Spengler J. C., Vallarino J., Geno P. W., Sun G., Yau A., "Identification of Selected Hormonally Active Agents and Animal Mammary Carcinogens in Commercial and Residential Air and Dust Samples," Journal of the Air and Waste Management Association, vol. 51, pp. 499-513, 2001. DOI: 10.1080/10473289.2001.10464292

[35] Rudel R. A., Camann D. E., Spen gler J. D., Korn L. R., Brody J. G., "Phthalates, Alkylphenols, Pesticides, Poly-brominated Diphenyl Ethers and Other Endocrine-disrupting Compounds in Indoor Air and Dust," Environmental Science and Technology, vol. 37, pp. 4543-4553, 2003. https://pubs.acs.org/doi/10.1021/es0264 596

[36] Barnes D. K. A., Galgani F., Thompson R. C., Barlaz M., "Accumulation and Fragmentation of Plastic Debris in Global Environments," Philosophical Transactions of the Royal Society B, vol. 364, pp. 1985-1998, 2009. https://doi.org/10.1098/rstb.2008.0205

[37] Dris R., Gasperi J., Mirande C., Mandin C., Guerrouache M., Langlois V., Tassin B., "A First Overview of Textile Fibers, including Microplastics, in Indoor and Outdoor Environments," Environmental Pollution, vol. 221, pp. 453-458, 2017. https://doi.org/10.1016/j.envpol.2016.12.0 13

[38] Shah A. A., Hasan F., Hameed A., Ahmed S., "Biological Degradation of Plastics: A Comprehensive Review," Biotechnology Advances, vol. 26, pp. 246-265, 2008. https://doi.org/10.1016/j.biotechadv.2007.12.005

[39] Peixoto D., Pinheiro C., Amorim J., Oliva-Teles L., Guilhermino L., Vieira M. N., "Microplastic Pollution in Commercial Salt for Human Consumption: A Review," Estuarine, Coastal and Shelf Science, vol. 219, pp. 161168, 2019. https://doi.org/10.1016/j.ecss.2019.02.018

[40] Samadi M., Huseien G. F., Mohammadhosseini H., Lee H. S., Shukor Lim N. H. A., Md Tahir M., Alyousef R., "Waste Ceramic as Low Cost and Eco-friendly Materials in the Production of Sustainable Mortars," Journal of Cleaner Production, vol. 266, 2020. https://doi.org/10.1016/j.jclepro.2020.121825

[41] Balegh B., Sellaf H., Hadjmostefa A., "Effect of Ceramic Waste on Mechanical and Geotechnical Properties of Tuff Treated by Cement," Case Studies in Construction Materials, vol. 13, 2020. https://doi.org/10.1016/j.cscm.20 20.e00368

[42] Juan A., Medina C., Ignacio Guerra M., Moran J. M., Aguado P. J., Sanchez de Rojas M. I., Frias M., Rodriguez O., "Re-Use of Ceramic Wastes in Construction, In: Wunderlich, W. (ed.)," Ceramic Materials, Rijeka, Croatia: Sciyo, pp. 197-214, 2010. http://www.intechopen.com/boo ks/ceramic-materials/re-use-of-ceramic-wastes-in-construc tion

[43] Amtered El-Abidi K. M., Mijarsh M. J. A., Faisal Abas N., "Properties of Porcelain Influenced Concrete," European Journal of Environmental and Civil Engineering, 2020. https://doi.org/10.1080/19648189.2019.1684383

[44] Zimbili O., Salim W., Ndambuki M., "A Review on the Usage of Ceramic Wastes in Concrete Production. World Academy of Science, Engineering and Technology," International Journal of Civil and Environmental Engineering, vol. 8, no. 1, pp. 91-95, 2014. https://www.semanticscholar.org/paper/A-Review-on-theUsage-of-Ceramic-Wastes-in-Concrete-Zimbili-Salim/a37 87356db097b1857fd96b7ea9dd5cc919ac448

[45] Singh A., Srivastava D. V., "Ceramic Waste in Concrete. A Review," IEEE International Conference Recent Advances on Engineering, Technology and Computational Sciences (RAETCS), 2018. https://www.researchgate.net/p ublication/324831930_Ceramic_waste_in_concrete-A_Rev iew

[46] Local Hazardous Waste Management Program in King County, Washington., "Ceramics in Art Hazards, 130 Nickerson St., Suite 100, Seattle, WA 98109-1658," http://www.hazwastehelp.org/ArtHazards/ceramics.aspx

[47] Abdullah M. M. A. B., Hussin K., Ruzaidi C. M., Baharin S., Ramly R., Nisa N. K., "Concrete Ceramic Waste Slab (CCWS)," Journal of Engineering Research and Education, vol. 3, pp. 139-145, 2006 https://jere.unimap.edu.my/images/Artikel/JERE\%20VOL \%203\%202006/JERE_3_2006_139-145.pdf

[48] Reig L., Tashima M. M., Soriano L., Borrachero M. V., Monzó J., Payá J., "Alkaline Activation of Ceramic Waste Materials," Waste and Biomass Valorization, vol. 4, no. 4, pp. 729-736, 2013. DOI: 10.1007/s12649-013-9197-z

[49] Raval A. D., N Patel D I., Pitroda P. J., "Ceramic Waste: Effective Replacement of Cement for Establishing Sustainable Concrete," International Journal of Engineering Trends and Technology (IJETT), vol. 4, no. 6, pp. 2324-2329, 2013. http://ijettjournal.org/volume-4/issue -6/IJETT-V4I6P121.pdf

[50] United State Department of Labor, Occupational Safety and Health Administration., "Silica, Crystalline - Health Effects (Silicosis)," 2021.https://www.osha.gov/silica-crys talline/health-effects

[51] Law of Malaysia, "Act 672, Solid Waste and Public Cleansing Management Act 2007" Percetakan Nasional Malaysia Berhad (Appointed Printer to the Government of Malaysia), Gazetted 2007, pp. 3-81. https://jpspn.kpkt.gov. 
my/resources/index/user_1/Perundangan/Akta-akta/act672 bi.pdf

[52] Tabak Y., Kara M., Gunay E., Yildirim S. T., Yilmaz S., "Ceramic Tile Waste as a Waste Management Solution for Concrete," 3rd International Conference on Industrial and Hazardous Waste Management, Chania (Crete, GR), 2012. https://www.researchgate.net/publication/297045994_cera mic_tile_waste_as_a_waste_management_solution_for_co ncrete

[53] Rautkoski H., Vähä-Nissi M., Kataja K., Gestranius M., Liukkonen S., Maattanen M., Liukkonen J., Kouko J., Asikainen S., "Recycling of Contaminated Construction and Demolition Wood Waste," Waste Biomass Valor, vol. 7, pp. 615-624, 2016. DOI: https://doi.org/10.1007/s12649 $-016-9481-9$

[54] Viance., "What is Treated Wood?" 2021. https://www.treatedwood.com/learn/what-is-treated-wood (accessed Mar. 25, 2021)

[55] Poon C. S., Yu A. T. W., Ng L. H., "On-site Sorting of Construction and Demolition Waste in Hong Kong," Resources, Conservation and Recycling, vol. 32, no. 2, pp. 157-172, 2001. https://doi.org/10.1016/S0921-3449(01)00 052-0

[56] Sathre R., Gonzalez-Garcia S., "Life Cycle Assessment (LCA) of Wood-based Building Materials," Eco-efficient Construction and Building Material, Woodhead Publishing, pp. 311-337, 2014. DOI: 10.1533/9780857097729.2.311

[57] Moghaddam A. Z., Mulligan C. N., "Leaching of Heavy Metals from Chromated Copper Arsenate (CCA) Treated Wood After Disposal," Waste Management, vol. 28, pp. 628-637, 2008. DOI: 10.1016/j.wasman.2007.03.009

[58] Solo-Gabriele H., Townsend T., Schert, J., "Environmental Impacts of CCA Treated Wood: A Summary from Seven Years of Study Focusing on the US Florida Environment," In: Presented at the 34th Annual IRG Meeting, Brisbane, Australia, IRG/WP 03-50205, 2003. https://scholar.google. $\mathrm{com} / \mathrm{scholar}$ ?hl=en\&as_sdt=0\%2C5\&q=Solo-Gabriele+H. $\% 2 \mathrm{C}+$ Townsend+T. $\% 2 \mathrm{C}+\mathrm{Schert} \% 2 \mathrm{C}+\mathrm{J} . \% 2 \mathrm{C}+\% \mathrm{E} 2 \% 80 \%$

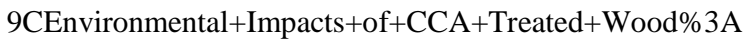
$+\mathrm{A}+$ Summary+from+Seven+Years+of+Study+Focusing+o $\mathrm{n}+$ the+US+Florida+Environment $\% 2 \mathrm{C} \% \mathrm{E} 2 \% 80 \% 9 \mathrm{D}+\mathrm{In} \%$ $3 \mathrm{~A}+$ Presented+at+the+34th+Annual+IRG+Meeting $\% 2 \mathrm{C}+$ Brisbane $\% 2 \mathrm{C}+$ Australia\%2C+IRG\%2FWP+03-50205\%2 $\mathrm{C}+2003 . \& \mathrm{btnG}=$

[59] Illman B. L., Highley T. L., "Fungal Degradation of Wood Treated with Metal-based Preservatives, The International Research Group on Wood Preservation," 1996. https://www.fpl.fs.fed.us/documnts/pdf1996/illma96b.pdf

[60] Shalat S. L., Solo-Gabriele H. M., Fleming L. E., Buckley B. T., Black K., Jimenez M., Shibatea T., Durbin M., Graygo J., Stephan W., Van DeBogart G., "A pilot Study of Children's Exposure to CCA Treated Wood from Playground Equipment," Science Total Environment, vol. 367, pp. 80-88, 2006. https://pubmed.ncbi.nlm.nih.gov/16 487576/

[61] Office of Environmental Health and Safety, Northeastern University., "Management of Paint and Paint Related Materials - General - What's Regulated," 2012. https://www.northeastern.edu/ehs/ehs-programs/hazardous -waste-management/fact-sheets/management-of-paint-and- paint-related-materials/

[62] Singh R., Vivek J. M., Rao B., Asolekar S. R., "Significance of the Presence of Asbestos in Construction and Demolition Wastes in India," In: Kalamdhad A., Singh J., Dhamodharan K. (eds) "Advances in Waste Management. Springer, Singapore," 2019. https://doi.org/1 0.1007/978-981-13-0215-2_21

[63] Subramanian V., Madhavan N., "Asbestos Problem in India," Lung Cancer, vol. 49, pp. 9-12, 2005. https://pubmed.ncbi.nlm.nih.gov/15950810/

[64] Ross M., Langer A. M., Nord G. L., Nolan R. P., Lee R. J., Van Orden D., Addison J., "The Mineral Nature of Asbestos," Regulatory Toxicology and Pharmacology, vol. 52, no. 1, pp. 26-30, 2008. https://pubmed.ncbi.nlm.nih.go $\mathrm{v} / 18423957 /$

[65] World Health Organization, Neira M., "Chrysotile Asbestos," 2014. https://www.who.int/ipcs/assessment/pub lic_health/chrysotile_asbestos_summary.pdf

[66] The Umweltbundesam., "Topics - Waste Containing Asbestos - Past Application Domains and Health Hazards," 2016. https://www.umweltbundesamt.de/en/topics/waste-r esources/waste-management/waste-types/hazardous-waste/ waste-containing-asbestos

[67] Suzuki Y., Yuen S. R., "Asbestos Fibers Contributing to the Induction of Human Malignant Mesothelioma," Annals New York Academy of Sciences, vol. 982, pp. $160-176$, 2002. DOI: 10.1111/j.1749-6632.2002.tb04931.x

[68] Miserocchi G., Sancini G., Mantegazza F., Chiappino G., "Translocation Pathways for Inhaled Asbestos Fibers," Environmental Health, vol. 7, no. 4, 2008. DOI: 10.1186/1476-069X-7-4

[69] United Nations Development Program., "Sustainable Development Goals," 2020. https://www.undp.org/content/ undp/en/home/sustainable-development-goals/

[70] Hong J., Kang H., An J., Choi J., Hong T., Park H. S., Lee D., "Towards Environmental Sustainability in the Local Community: Future Insights for Managing the Hazardous Pollutants at Construction Sites," Journal of Hazardous Materials, vol. 403, 2021. https://doi.org/10.1016/j.jhazmat .2020 .123804

[71] Planning and Construction News., "Dealing with Hazardous Waste in Construction - What is Hazardous Waste and How Can You Handle It?" 2019. https://www.pbctoday.co.uk/news/planning-construction-n ews/hazardous-waste-construction/53765/

[72] Masood A., Ahmad T., Arif M., Mahdi F., "Waste Management Strategies for Concrete," Environmental Engineering and Policy, vol. 3, no. 1, pp. 15-18, 2002. DOI: $10.1007 / \mathrm{s} 100220100034$

[73] Oikonomou N. D., "Recycled Concrete Aggregate," Cement and Concrete Composites, vol. 27, no. 2, pp. 315-318, 2005. https://www.researchgate.net/publication/2 22515274_Recycled_concrete_aggregates

[74] Wahi N., Joseph C., Tawie R., Ikau R., “Critical Review on Construction Waste Control Practices: Legislative and Waste Management Perspective," Procedia - Social and Behavioral Sciences, vol. 224, pp. 276-283, 2016. 
https://doi.org/10.1016/j.sbspro.2016.05.460

[75] Tam V. W. Y., Shen L. Y., Fung I. W. H., Wang J. Y., "Controlling Construction Waste by Implementing Governmental Ordinances in Hong Kong," Construction Innovation: Information, Process, Management, vol. 7, no. 2, pp. 149-166, 2007. https://www.emerald.com/insight/co ntent/doi/10.1108/14714170710738522/full/html

[76] Environmental Protection Department., "A Concise Guide to the Air Pollution Control Ordinance Hong Kong, (March)," 2010. https://www.epd.gov.hk/epd/english/envir onmentinhk/air/guide_ref/guide_apco.html

[77] Environmental Protection Department., "A Guide to the EIA Ordinance in English Version," 2011. https://www.epd.gov.hk/eia/english/guid/index1.html

[78] Agamuthu P., Fauziah S. H., "Challenges and Issues in Moving Towards Sustainable Landfilling in A Transitory Country - Malaysia," Waste Management and Research: The Journal of the International Solid Wastes and Public Cleansing Association, ISWA, vol. 29, pp. 13-19, 2011. DOI:10.1177/0734242X10383080

[79] Sasitharan N., Ismail A. R., Ade A., "Construction Waste Management: Malaysian Perspective," The International Conference on Civil and Environmental Engineering
Sustainability (IConCEES 2012), 3-5 April 2012, Thistle Hotel, Johor Bahru, Malaysia, pp. 229-309, 2012. https://www.researchgate.net/publication/258224407_cons truction_waste_management_malaysian_perspective

[80] Butera S., Christensen T. H., Astrup T. F., "Life Cycle Assessment of Construction and Demolition Waste Management," Waste Management, vol. 44, pp. 196-205, 2015. DOI:10.1016/j.wasman.2015.07.011. 2015

[81] Hauschild M. Z., Wenzel H., "Environmental Assessment of Products," Volume 2: Scientific Background. Chapman and Hall, London, England (ISBN 0-412-80810-2), 1998. https://www.springer.com/gp/book/9780412808104

[82] Yeheyis M., Hewage K., Shahria Alam M., Eskicioglu C., Sadiq R., "An Overview of Construction and Demolition Waste Management in Canada: A Lifecycle Analysis Approach to Sustainability" Clean Technologies and Environmental Policies, vol. 15, no. 1, pp. 81-91, 2013. DOI: $10.1007 / \mathrm{s} 10098-012-0481-6$

[83] Stanley S., "USGBC (The U.S. Green Building Council), U.S. Green building council announces top 10 countries and regions for LEED green building", 2019. https://www.usgbc.org/articles/us-green-building-council-a nnounces-top-10-countries-and-regions-leed-green-buildin $\mathrm{g}$ 